\title{
Cooperative and national agricultural farm as total institutions
}

\section{Spółdzielcze i państwowe gospodarstwa rolne jako instytucje totalne}

\author{
Andrzej Borowski \\ Department of Sociology and Social Works, Faculty of Education and Philosophy, \\ Pomeranian University in Słupsk, 64 Westerplatte St., 76-200 Słupsk, Poland \\ E-mail address: aubor@poczta.onet.pl
}

\begin{abstract}
Functioning and noticing cooperative and national agricultural farm as total institutions is connected with comprehending the collectivization, understood as converting individual agricultural farm into farming cooperatives (v. RSP, the collective farm), of craftsman's workshops into production cooperatives, and the like and of large manors into agricultural farm stewarded by the state. In frames of all institutional forms of cooperative and national planting the earth some stamps of total- institutions became discernible the concentration of functioning on the homogeneous area relatively isolated in terms of physics or culturally from the social environment, the division into subordinates and the staff, functioning of second living in the institution in such conditions are an Effect of functioning of people dominating of a welfare state mentality and the lack of the initiative in search for employing outside the domicile.
\end{abstract}

Keywords: collective farm; National Agricultural Farm; total institution; collectivization

\section{STRESZCZENIE}

Funkcjonowanie i postrzeganie spółdzielczych i państwowych gospodarstw rolnych jako instytucji totalnych wiąże się $\mathrm{z}$ pojęciem kolektywizacji, rozumianej jako przekształcanie indywidualnych gospodarstw rolnych w spółdzielnie rolnicze (zob. RSP, Kołchoz), warsztatów rzemieślniczych w spółdzielnie produkcyjne, itp. oraz dużych posiadłości ziemskich w zarządzane przez państwo gospodarstwa rolne. W ramach wszystkich instytucjonalnych form spółdzielczego i państwowego uprawiania ziemi dostrzegalne się stały niektóre cechy instytucji totalnych - koncentracja funkcjonowania na jednolitym terenie stosunkowo odizolowanym fizycznie lub kulturowo od otoczenia społecznego, podział na podwładnych i personel, funkcjonowanie drugiego życia w instytucji. Efektem funkcjonowania ludzi w takich warunkach jest dominowanie postawy roszczeniowej i brak inicjatywy w poszukiwaniu zatrudnienia poza miejscem zamieszkania.

Stowa kluczowe: Rolnicza Spółdzielnia Produkcyjna, Państwowe Gospodarstwo Rolne, instytucja totalna, kolektywizacja. 


\section{WPROWADZENIE}

Funkcjonowanie i postrzeganie spółdzielczych i państwowych gospodarstw rolnych jako instytucji totalnych wiąże się z pojęciem kolektywizacji, rozumianej jako przekształcanie indywidualnych gospodarstw rolnych w spółdzielnie rolnicze (zob. RSP, Kołchoz), warsztatów rzemieślniczych $\mathrm{w}$ spółdzielnie produkcyjne, itp. oraz dużych posiadłości ziemskich $\mathrm{w}$ zarządzane przez państwo gospodarstwa rolne. Proces kolektywizacji jaki występował zwłaszcza w XXw.cechowało stosowanie przymusowych dostaw żywności (kontyngentów) oraz zwiększone obciążenia podatkowe, oddziaływanie aparatu administracyjnego, policyjnego i propagandowego oraz przemoc fizyczna prowadząca w niektórych krajach nawet do terroru państwowego. Żródeł takiego postrzegania tych instytucji należałoby szukać w początkach istnienia ZSRR, gdzie początkowo od 1922 powstawały dobrowolne komuny i zrzeszenia drobnotowarowych producentów rolnych (tzw. artele), które nawiązywały do rosyjskich wspólnot wiejskich, zwanych obszczinami.

\section{FUNKCJONOWANIE KOLEKTYWNYCH FORM INSTYTUCJI ROLNICZYCH}

Wprowadzony przez Lenina w 1921 program gospodarczy NEP, przewidywał liberalizację polityki rolnej. Po śmierci Lenina od 1925 rozpoczął się jednak proces odchodzenia od tej polityki zakończony w 1929 całkowitym zaniechaniem programu, przy jednoczesnym wzmocnieniu nacisku aparatu państwowego w zakresie ekonomicznym i administracyjnym, zmierzającym do procesu wymuszonego tworzenia kołchozów. W 1929 Józef Stalin rozpoczął politykę przymusowej kolektywizacji rolnictwa w ZSRR. Proces kolektywizacji przyspieszono w styczniu 1930, głównie w regionach o dużym poziomie produkcji zbożowej, stosując masowy terror wymierzony zwłaszcza w silnych ekonomicznie bogatych chłopów określanych jako tzw. kułacy. Terror został następnie skierowany również w małorolnych i średniorolnych chłopów, których wraz z rodzinami wysyłano do łagrów lub deportowano na Syberię. W latach 1930-1933 kolektywizacja doprowadziła do załamania cyklu produkcyjnego $\mathrm{W}$ rolnictwie na Ukrainie, gdzie zwiększone kontyngenty żywnościowe nałożone na wieś i represje władz, spowodowały bojkot kołchozów sowieckich przez ukraińskich chłopów. Do roku 1934 zakończono kolektywizację w ZSRR (europejska część Rosji, Białoruś i Ukraina) a do 1938 (Daleki Wschód). Gospodarstwa przekształcone w państwowe nazywane były w Związku Radzieckim sowchozami, a w spółdzielcze kołchozami. Różnica była w praktyce semantyczna (istotą kolektywizacji było wywłaszczenie i przekształcenie rolników-gospodarzy w państwowych robotników rolnych - parobków). Przeciwników wprowadzanych przez Stalina zmian zsyłano do obozów koncentracyjnych GUŁag. Podczas kolektywizacji wszyscy chłopi na terenie ZSRR zostali zmuszeni do oddania swoich gospodarstw i inwentarza. Chłopi bronili się przed Przymusowa kolektywizacja w wydaniu sowieckim różniła się istotnie od dobrowolnych form spółdzielczości rolnej, przynoszących wymierne efekty ekonomiczne (np.y kibuce na terenie Palestyny i Izraela). Na terenie Polski proces kolektywizacji rozpoczął się po II wojnie swiatowej od... parcelacji czyli podziału gruntów po byłych folwarkach i gospodarstwach junkierskich na mniejsze działki i oddanie ich w użytkowanie indywidualnym gospodarstwom w drodze sprzedaży.

Po II wojnie światowej, przy likwidacji wielkiej własności na ziemiach przedwojennej Polski, przymusowa parcelacja, objęła ok. 1,2 mln ha natomiast na tzw. Ziemiach Odzyskanych rozdzielono ok. $5 \mathrm{mln}$ ha ziemi. Ziemia która nie została rozpoarcelowana i nie zyskała nowych 
właścicieli w pierwszych latach po wojnie stała się bazą do utworzenia Państwowych Gospodatstw Rolnych.

W Polsce decyzję o kolektywizacji rolnictwa podjął KC PPR we wrześniu 1948r równolegle do podobnych decyzji wymuszonych na krajach socjalistycznych przez ZSRR. Przymus kolektywizacyjny, stosowany w różnej formie przez władze komunistyczne, przy jednoczesnym wzroście obciążeń produkcyjnych gospodarstw prywatnych, po 1950 doprowadził do spadku produkcji rolnej i stworzył perspektywę szybkiej ruiny rolnictwa $\mathrm{w}$ kraju. Po zmianach politycznych Października 1956, Władysław Gomułka oficjalnie uznał prywatne rolnictwo w Polsce jako specyfikę tzw. polskiej drogi do socjalizmu, a władze komunistyczne rezygnowały stopniowo z przyspieszonej kolektywizacji. Liberalizacja polityki w tym zakresie, zmniejszenie obciążeń finansowych gospodarstw indywidualnych, spowodowały gwałtowny regres systemu spółdzielni. Apogeum przymusowej kolektywizacji miało miejsce $\mathrm{w}$ 1953. Tymczasem już w poczatku lat 60-tych we wszystkich krajach bloku sowieckiego z wyjątkiem Polski, rolnictwo zostało w większości skolektywizowane.

Zupełnie inny przebieg miała kolektywizacja na terenie Chin, Tworzenie tzw. komun ludowych rozpoczęto $\mathrm{w} 1957 \mathrm{w}$ ramach realizowania polityki tzw. trzech czerwonych sztandarów Mao Zedonga. W przeciągu trzech miesięcy przymusowo włączono w ich obręb 99\% gospodarstw rolnych w Chinach i 740 tysięcy spółdzielni produkcyjnych. Ostatecznie na obszarze całego kraju powstało 26 tysięcy takich komun. System komun ludowych w przeciągu dwóch lat doprowadził do zapaści gospodarczej i klęski głodu w Chinach, przyczyniając się do klęski wielkiego skoku. System komun ludowych powrócił ponownie wraz z początkiem rewolucji kulturalnej w 1967 roku. Ponownie odebrano chłopom prawo do hodowli przyzagrodowej, a na wieś zesłano ogromną liczbę ludzi uznanych za przeciwników rewolucji celem reedukacji przez pracę. W zatwierdzonej w 1975 roku nowej konstytucji ChRL zapisano prawnie komuny ludowe jako państwowy system organizacji produkcji rolnej, co potwierdziła kolejna konstytucja z 1978 roku. Kres komunom ludowym przyniosły dopiero śmierć Mao Zedonga i reformy gospodarcze zainicjowane przez Deng Xiaopinga na początku lat 80 . W ramach wszystkich instytucjonalnych form spółdzielczego i państwowego uprawiania ziemi dostrzegalne się stały niektóre cechy instytucji totalnych - koncentracja funkcjonowania na jednolitym terenie stosunkowo odizolowanym fizycznie lub kulturowo od otoczenia społecznego, podział na podwładnych i personel, funkcjonowanie drugiego życia w instytucji.

Kołchozy, PGR-y i kibuce to rodzaj otwartych instytucji totalnych w któryxch może występować minimalne lub połowiczne ubezwłasnowolnienie społeczne członków. Jedną z bardziej charakterystycznych instytucji tego typu stały się kołchozy,które formalnie były rolniczą spółdzielnią produkcyjną. Kołchozy powstawały w wyniku zwykle przymusowego przejęcia ziemi od indywidualnych rolników na rzecz państwa, w ramach kolektywizacji rolnictwa. Od tradycyjnych spółdzielni funkcjonujących w innych krajach kołchozy różnią się tym, że wspólnota nie ma prawa się rozwiązać i żaden jej członek nie ma prawa z uczestnictwa $\mathrm{W}$ niej zrezygnować. Po wprowadzeniu w ZSRR obowiązku posiadania dokumentów osobistych w 1932 roku aż do 1976 r. nie wydawano ich chłopom, co uniemożliwiało lub utrudniało im odejście z kołchozu. W niemal nienaruszonej wersji funkcjonują do dzisiaj na terenie Białorusi.

Kołchozy w innych krajach /przede wszystkim socjalistycznych/, funkcjonowały na podobnych zasadach pod takimi nazwami jak:

- Rolnicza Spółdzielnia Produkcyjna (RSP) - Polska

- Landwirtschaftliche Produktionsgenossenschaft (LPG), także ogrodnicze Gärtnerische Produktionsgenossenschaft (GPG) - NRD

- Jednotné zemědělské družstvo, Jednotné rol'nícke družstvo - Czechosłowacja 
- Termelöszövetkezet - Węgry

- Kooperativa bujqësore - Albania

- TKZS (TKЗC) - Bułgaria

- Kibuc - Izrael

Nieco inny ustrój wewnętrzny miała forma zaproponowana przez kibuce, która powstała w 1910r. będąc połączeniem instytucji rolniczej spóldzelni ze wspólnotą etniczno-religijną. Ideowym podłożem powstawania kibucu jest połączenie syjonizmu z socjalizmem; Mieszkańcy kibucu nie mają własnego majątku, posiadają równe prawa i obowiązki; decyzje dotyczące strategii gospodarczej i podziału dochodów podejmuje walne zebranie kibucników; ono też wybiera komitet kierujący życiem kibucu między walnymi zebraniami. Przynależność do wspólnoty jest dobrowolna. Obecnie funkcjonuje 256 kibuców z tego tylko 16 o charakterze religijnym, pozostałe zostały w miarę napływu ludności żydowskiej po II wojnie stworzone jako świeckie wspólnoty rolnicze. Populacja kibuców stanowi ok 2,5 \% ludności Izraela. W całym układzie życia kibucowego najważniejsza staje się obecnie troska o zapewnienie warunków sprzyjających rozwojowi indywidualności każdej jednostki i jej indywidualnego sposobu życia przy zachowaniu niezbędnej więzi ze wspólnotą [1].

Państwowe formy instytucji gospodarującej ziemią rolną również powstały w ZSRR, i zyskały miano sowchozów. Sowchozy, w odróżnieniu od kołchozów, były tworzone z ziemi zarekwirowanej od dawnych wielkich właścicieli ziemskich w ramach reformy rolnej, a nie od indywidualnych, drobnych rolników. Cały majątek sowchozów należał zatem od początku tylko do państwa, zaś status zatrudnionych w nich ludzi miał charakter pracowników najemnych. Na terenie Polski ten typ funkcjonowania charakteryzował Państwowe Gospodarstwo Rolne PGR) jako formę socjalistycznej własności ziemskiej w latach 19491993. Po przejściu na gospodarkę rynkową na podstawie ustawy z 19 października 1991 roku o gospodarowaniu nieruchomościami rolnymi Skarbu Państwa Państwowe Gospodarstwa Rolne zostały zlikwidowane, a ich majątek został przejęty przez Agencję Własności Rolnej Skarbu Państwa (obecnie Agencja Nieruchomości Rolnych). Gospodarstwa, które nie zostały sprzedane lub wydzierżawione, były w zarządzie Agencji i zarządzane przez administratorów wyznaczonych przez Agencję. Większość PGR-ów zlikwidowano w roku 1991, a ostatecznie wszystkie PGR-y zlikwidowano 31 grudnia 1993. Nieliczne przekształcono w Gospodarstwa Rolne Skarbu Państwa.

Osiedle PGR-owskie, jak podaje B. Jałowiecki, to całość ekologiczna o jednorodnym charakterze, stanowiąca subregion nie tylko w gospodarczym ale i społeczno-demograficznym sensie [2].

Pierwszą choć nie najważniejszą cechą wsi PGR- owskiej, w okresie po wojennym, był fakt mniej lub bardziej widocznego rozgraniczenia części chłopskiej od pozostałej. Przejawiało się to zarówno w płaszczyźnie zabudowy jak i społecznej, konstatuje Z. Zychowicz [3].

Początkowe lata funkcjonowania PGR-ów to okres dużego izolacjonizmu. Izolacjonizm ten wynikał z faktu, iż:" Rolnicy indywidualni subiektywnie odczuwali własną przewagę nad częścią PGR-owską z uwagi na: efekty ekonomiczne, wyższy prestiż społeczny, większą kontrolę społeczną. Pracownicy PGR odczuwali własną przewagę nad resztą mieszkańców wsi $\mathrm{z}$ uwagi na poziom życia, wykształcenie, postęp techniczny w zakładzie, udział w kulturze masowej. Osiedle PGR-owskie wobec mniej rozgałęzionych więzów pokrewieństwa oraz większego zróżnicowania mieszkańców, $\mathrm{w}$ porównaniu $\mathrm{z}$ tradycyjną wsią rolników indywidualnych- nie jest społecznością" swoich", którym przyznaje się prawo do ingerencji czy do większego wglądu w sprawy osobiste” zauważa M. Ignar [4]. 
Od lat sześćdziesiątych na szeroką skalę zaczęły powstawać specyficzne formy zabudowy wiejskiej. W miejsce przedwojennych czworaków powstały osiedla PGR -owskie z wszelkimi znamionami betonowych osiedli miejskich /szpetota, dysfunkcjonalny charakter, skrajna uniformizacja, izolacja, zatruwanie środowiska przez kotłownie/. Na wygląd części pegeerowskiej wsi rzutował ex definitione sam, zakład rolny. Specyfiką życia rodzinnego środowiska PGR jest, jak podaje J. Biernat, jedność miejsca najemnej pracy zawodowej, zamieszkania i w niemałej mierze także wypoczynku [5].

Już w połowie 1993r. jak zauważył Z. Grzelak, „,socjologowie badający tereny dawnych PGR-ów zastawali pustkę, apatię ludzi nikomu niepotrzebnych, brutalnie odcinanych od świata przez brak połączeń komunikacyjnych i spychanych po skończonym okresie pobierania zasiłku dla bezrobotnych na dno nędzy. Zbieranie runa leśnego celem minimalizacji kosztów wyżywienia sygnalizuje zdaniem tego autora powrót do ery dzikości". Wspomniany wyżej paternalizm w społeczności PGR- owskiej $\mathrm{W}$ zderzeniu zwolnym rynkiem stał się dla większości byłych pracowników tych gospodarstw katastrofą osobistą i rodzinną [6]. Dominuje postawa roszczeniowa i brak inicjatywy w poszukiwaniu zatrudnienia poza miejscem zamieszkania.

\section{WNIOSKI}

W wyniku analizy uzyskanych danych celowym byłoby wyodrębnienie zarówno dla dalszych celów badawczych jak również dla celów działalności socjalnej podmiotów pomocy społecznej następujących kategorii osiedli popegeerowskich:

- osiedla zaniedbane infrastrukturalnie z bardzo niską lub niską aktywnością mieszkańców, - osiedla zaniedbane infrastrukturalnie z średnią aktywnością mieszkańców,

- osiedla zaniedbane infrastrukturalnie z wysoką i bardzo wysoką aktywnością mieszkańców,

- osiedla o dobrej infrastrukturze przy bardzo niskiej lub niskiej aktywności mieszkańców,

- osiedla o dobrej infrastrukturze przy średniej aktywności mieszkańców,

- osiedla o dobrej infrastrukturze przy wysokiej aktywności mieszkańców.

W przypadku pierwszych trzech typów osiedli wskazane byłoby podjęcie kompleksowych działań zarówno w sferze inwestycji infrastrukturalnych oraz konstrukcji programów aktywizacyjnych. W przypadku trzech pozostałych działania podmiotów pomocy społecznej powinny skoncentrować się na pobudzaniu i wspieraniu aktywności społecznej mieszkańców [7].

Stopień aktywności mieszkańców/ uprzednio uczestników uspołecznionych instytucji rolniczych/ jest bezpośrednio zależny od stopnia ubezwłasnowolnienia będącego jednym ze wskaźników totalności instytucji [8-11].

\section{References}

[1] A. Lewin, Kibuce w Izraelu, Warszawa 1992, s. 95.

[2] B. Jałowiecki, Niektóre problemy odrębności struktury przestrzenno-społecznej osiedli PGR na przykładzie powiatu wrocławskiego. Roczniki Socjologii, WSI, tom 5, 1966.

[3] Z. Zychowicz, M. Jędryczka, Współczesny wizerunek dawnej wsi pegeerowskiej. Stare $i$ nowe struktury społeczne w Polsce, t. 2 Wieś /red. I. Machaj, J. Styk/, Lublin 1995, s. $197-200$. 
[4] M. Ignar, Społeczne i zawodowe problemy funkcjonowania PGR, Socjologiczne aspekty funkcjonowania sektora uspołecznionego w rolnictwie, /red. F. Mleczko, Z. Zychowicz/, Szczecin, 1987 s. 109-124.

[5] J. Biernat, Z badań nad rodzinami pracowników PGR, Wieś Współczesna, nr 2, 1987.

[6] Z. Grzelak, Refleksje o kondycji polskiej socjologii wsi, w: Stare i nowe struktury społeczne w Polsce, t. 2 Wieś /red. I. Machaj, J. Styk/, Lublin 1995, s. 263.

[7] A. Borowski, Studia Sociologica (Szczecin) 16 (2006) 215-234

[8] A. Borowski, International Letters of Social and Humanistic Sciences 1 (2013) 14-18.

[9] A. Borowski, International Letters of Social and Humanistic Sciences 4 (2013) 70-74.

[10] A. Borowski, International Letters of Social and Humanistic Sciences 6 (2013) 86-90.

[11] A. Borowski, International Letters of Social and Humanistic Sciences 7 (2013) 113-118. 